\title{
Trade Union Leaders at the Plant Level and Their Perspective on Trade Union Management and HR Practices: A Case Study
}

\author{
Dr. M. Srimannarayana \\ Professor of Human Resource Management \\ XLRI \\ Jamshedpur, India
}

$\begin{array}{lrr}\text { Received: Nov. 6, } 2015 & \text { Accepted: Dec. 17, } 2015 \quad \text { Published: January 1, } 2016 \\ \text { doi:10.5296/jmr.v8i1.8683 } & \text { URL: http://dx.doi.org/10.5296/jmr.v8i1.8683 }\end{array}$

\begin{abstract}
The present study aimed at identifying the profile of trade union leaders operating at a plant level in India and to find out their viewpoint on trade union management and HR practices of their plant. The data collected from 81 local trade union leaders using an interview schedule is the basis for the study. The study finds that that an average trade union leader is a middle aged, educated, urbanite employee of the plant with multilingual proficiency. He has joined in the union with a genuine interest of serving working class. However, increasing expectations of the members makes his job difficult. He firmly believes that mutual discussions, negotiations and legal methods are the best means of achieving union objectives. $\mathrm{He}$ is happy with the present HR practices existing in the Plant. Though there is a feeling that intensity of work and workload are increased, he believes that improved quality of working conditions, increased employee benefits and services, and learning opportunities make the employees happy. Finally, he is willing to sacrifice the sectional interests of the members for the long term benefit of the plant.
\end{abstract}

Keywords: HR perspective of trade union leaders, plant level union leaders' profile, trade union, trade union management 


\section{Introduction}

Trade unions in India operate at national, regional, local and plant levels. While the national and regional federations are concerned with government labour policy, local or plant level unions are largely interested in the small section of their workers (Sheth and Jain, 1968). At any level of union, leadership makes a difference to workers and organisational outcomes in most workplace settings (Day and Harrison, 2007; Piccolo and Colquitt, 2006; Walumbwa et al., 2008). Leadership implies an intentional process that influences structure and facilitates activities and relationships in a group or association. The type of trade union leadership is a great extent dependent upon the context, the psychology of the leader, and socio-psychological composition of the led (Punekar and Madhuri, 1967). The psychology of the leaders depends on various factors including their background. An attempt is made in this study to find out the profile of trade union leaders operating at a plant level in India and to assess their views on various aspects of trade union management, and their perspective on the HR practices of their plant.

\section{Earlier studies}

Punekar and Madhuri, (1967) made an attempt to find out the types of trade union leadership, according to their socio-economic and psychological characteristics, to identify leaders' attitudes on various trade union problems, and to bring out the profile of Indian trade union leaders. The study covered different trade unions working in different regions of India. It found that trade union leaders call themselves 'humanitarian', with considerable education, and that they joined the trade union movement to improve the lot of workers. The study further found that almost one-thirds of the leaders were outsiders to the organisations. They took more than only professional interest in trade unionism and workers welfare. According to the leaders of the study, the aim of a trade union should be the achievement of higher wages and better working conditions.

Acharji (1980) conducted a study in an industrial city of India to draw a profile of trade union leaders at a micro level having their base in the various units of manufacturing and service industries. The study found that common socio-economic interests of working class helped it to transcend the ethnic, religious and linguistic barriers. The study further found that the leaders were not politically affiliated. There was predominance of employee and ex-employee leaders over outsiders. The employee leaders, who were working in the same plant,were economically and socially nearer to their members, but had limited scope for contributing to union strength especially when the collective bargaining was plant-wise.

Sood (1984) conducted a study on trade union leaders in Punjab, one of the states in India, to ascertain the prevailing social and political alignments of the trade union leaders. This study found that the trade union movement was dominated by a middle-aged leadership was incorrect. According to this study, the trade union leaders were politically linked, consciously or subconsciously ideologically motivated, fairly militant and committed individuals. They were satisfied with the attitude of the general public, intellectuals, and workers towards the trade union movement. However, the trade union leaders felt that the attitude of management was hostile and government was perceived as a better employer than the private entrepreneur. 
They considered personal integrity, sincerity and ability to understand the workers as the characteristics of a good union leader.

Madhusudana Rao (1984) conducted a study on union leaders in Visakhapatnam, one of the industrial cities in India, to draw their profile. The study found that the Hindus were dominating leaders. A majority of them were immigrants with rural background. The leadership in the city was predominately dominated by employee leaders. Only a few leaders had political affiliations and they did not find much time to engage in social service activities. They joined in the union with a genuine desire to serve the workers.

Masihi (1985) conducted a study on trade union leaders in a textile city of India to examine their social background, their leadership role and their views on various aspects of industrial relations. The study found that the leaders were predominantly homogenous in terms of language and nativity, but heterogeneous in terms of caste and culture. It was further found that the trade union leaders had to perform multiple roles and tasks relating to their members and their organisations. The members had extra-union demands which they expected the leaders to meet. The diversity of roles and consequent lack of time created difficulties to the trade union leaders.

Hiremath (1990) made an attempt to study trade union leadership in Karnataka, one of the States in India. The study aimed at assessing the role played by trade union leaders, their career patterns and attitudinal factors. This study revealed that an overwhelming majority of the trade union leaders were from the ranks of workers. Coming to career aspects, the study reported that union leadership was not developed as a profession in itself. It was looked upon as an honorary work. The span of union career was significantly associated with age, and inside-outside status of the union leaders. This study found three types of union leaders such as 'the union boss', an outsider with distinct political party orientation, 'the plant leader', an insider, restricted himself to the plant politics and tried to make the best out of it, and 'the neophyte, the beginner with low union status. With regard to the role of union leaders in the system of industrial relations, the study identified that, being employee leaders (the plant leader and the neophyte) their role was considered 'low'.

\section{Methodology}

The purpose of the present study was to draw a profile of union leaders of a plant level and to find out their viewpoint on various aspects of trade union management and HR practices prevailing in their plant. Taking into consideration, the inputs from earlier studies conducted in India in this area, an interview schedule was developed. As a part of pre-testing, the interview schedule was administered on two office bearers and one executive committee member of the Union. Based on the inputs received, it was revised and finalized by deleting, adding and altering some of the questions. The population of the study constituted 11 office bearers and 214 executive committee members. The information was collected using the interview schedule from 114 respondents based on stratified random basis covering all office bearers and representative number of executive committee members. Care was taken to include executive committee members proportionately, working in different departments of the plant as employees. The data was collected from April, 2012 to June, 2012. After 
reviewing the filled-in interview schedules, it is found that there were 81 filled-in interview schedules which consisted of complete information. Thus the sample of the respondent union leaders for the study remained as 81 . In addition to this data, the Union's Constitution and Rule Book and personal observations of investigators were other sources of information for the study. The data collected analyzed qualitatively and quantitatively using percentages.

\section{The Plant}

The Union selected for this study, organized employees of a metal plant in India, located in an industrial town in India, which had a population around one million. A majority of long-time residents of this town came from all over the country and settled in the town. ThePlant was an integral part of one of the largest companies in India. Having incorporated in 1907 , the company gradually expanded its operations to foreign countries. It was one of the most respected companies in India. The Plant employed around 1600 personnel in different departments. Basically, it had a paternalistic attitude towards its employees. It started providing many health, welfare and safety facilities to its employees from its inception, even without any legal compulsions. It maintained a good track record of successful industrial relations.Over a period of time, it had acquired great reputation for its human resource policies and ethical conduct.The Plant gave great importance to sustainable development. It worked with various bodies from local to global to ensure sustainable development. It was aspiring to be a global benchmark in value creation and corporate citizenship.A performance culture, safety and social responsibility, continuous improvement, openness and transparency were integral parts of the company's culture.

\section{The Union}

\subsection{Brief History and Achievements}

The union was one of the earliest trade unions in India. It was established in 1920. Like any other union, the objectives of the Union were: to secure, protect and safeguard the interests of its members; to ameliorate and improve the living and service conditions of its members; and to regulate the relations between the members and their employer. Its membership was over 93\%. Historically, this union was always under the stable and matured leadership.It was headed by either employees or former employees of the company. However, it was affiliated to Indian National Trade Union Congress (INTUC). It was the only union recognized by the management since its origin. The Union and the management of the Plant entered into 19 collective bargaining agreements between 1920 and 2008. It always maintained cordial relations with management and all financial, social and fringe benefits gained through non-violent and peaceful means. Since 1928 there was no strike initiated by the Union.

In addition to collective bargaining, the Union undertook some welfare measures on its own for the benefit of its members and their families. In 1962, the Union opened two high schools for the education of its members' children. State government took over the charge of running these schools over a period of time. In 1954 the Union introduced a sickness benefit scheme for the benefit of its members in the event of their sickness, causing loss of pay. The Union gave gifts to retired employees, who were the members of the Union. It considered the improvement 
of workers' education and awareness level as one of its responsibilities. It established a center for this purpose, which conducted training and developmental programmes for workers and supervisors.It published an in-house journal to provide up-to-date information to its members.

\subsection{Structure and Functions of the Union}

The Union was managed by an executive committee composed of office bearers and executive committee members. One President, one Deputy President, four Vice-Presidents, one General Secretary, three Assistant Secretaries and one Treasurer were the office bearers of the Union. Executive committee members elected these office bearers in its first meeting. The President guided the affairs of the Union and presided over all meetings of the Union and executive committee. The Deputy President performed the duties as may be delegated to him by the President and he performed all duties of the President in his absence. The Vice-President performed the duties as may be delegated to him by the President and also all duties of the Deputy President in his absence. The General Secretary was responsible for the entire management of the Union. The Assistant Secretaries helped the General Secretary in managing the work of the Union. Each Assistant Secretary was assigned a department or couple of departments as specified by the executive committee. The Treasurer was responsible for money received and disbursed. The executive committee consisted of 214 members duly elected by the general body of the members of the Union for two years. The employees of different departments of the Plant, who were members of the Union, were proportionately represented in the executive committee. In addition to electing office bearers of the Union, the executive committee was responsible for managing and controlling all internal and external affairs of the Union. It appointed employee representatives for the joint committees operating in the Plant. It elected members to represent the Union at all India level. It was responsible to raise funds and donations. Generally, it met at least once in two months. The quorum required for a meeting was one-fourth of its members.

\section{General Background of the Trade Union Leaders}

The general background information of respondent union leaders such as their age, native place, migration status, religion, education, languages known to them, their job responsibilities and membership in voluntary organisations were presented in Table. 1.

\subsection{Age}

Age wise, it was found that almost every alternative trade union leader was in the age group of $46-55$ years. The average age was calculated as 49 years with the minimum 35 years and maximum age of 65 years. When compared to an earlier study (Acharaji, 1980) in which the average age was 42.24 years, it seemed that the average age of the leaders was increased by seven years. Masihi (1985) and Hiremath (1990) found that the higher percentage of trade union leaders were middle aged.

\subsection{Rural-Urban Background}

With respect to rural-urban background, a simple majority (54\%) of the union leaders of this study had an urban background. This group consisted of second and third generation of 
urbanized group, who were born and brought up in the industrial city. This is consistent with the findings of an earlier study of Masihi (1985) on the union leaders in a textile city. However, it is inconsistent with the study on union leaders in a port city (Madhusudana Rao, 1984), which found that the majority of the leaders were from rural background.

\subsection{Religion and Family Background}

Religion wise, an overwhelming majority (92.59\%) were Hindus. However, Muslims (4.94\%), Christians (1.23\%), and Sikhs (1.23\%) were also represented in the group of trade union leaders. Similar observations could be seen in earlier studies (Punekar and Madhuri, 1967; Acharji, 1980; Sood 1984; Madhusudana Rao, 1984; Masihi, 1985). It appeared that Hindus continued to be a majority group among trade union leaders over a period of time in India. It might be reflecting the religious composition of India, which composed of an overwhelming majority of Hindus in Indian population. When it came to family background, it was observed that all the respondent union leaders of the study were married. The average size of their household was calculated as 4.7 members.

\subsection{Education}

As far as educational background is concerned, a majority (61.73\%) of them had technical education such as certification from Industrial Training Institutes or Polytechnic Colleges. $33.33 \%$ of them had general educational qualifications such as graduation or post-graduation in arts or sciences or commerce. The respondent leaders of the study were, predominately, employee leaders, who worked as full time employees of the Plant. The Plant generally recruited people with technical qualification in various positions in its operation related departments. Hence it is natural to see a majority of the union leaders with technical qualifications. Similar trends were found in some of the earlier studies (Acharji, 1980; Masihi, 1985).

\subsection{Fluency of Languages}

With respect to this aspect, it is significant to note that more than half of the respondents could speak two languages i.e. English and Hindi. In addition to these two languages, some of them could speak one or two regional languages too. The Plant employed people in the worker category, basically from the same industrial town where the Plant was located. A majority of long-time residents of this town came from different regions of India. Each region had its own language. Therefore, one can find multi lingual proficiency among the respondent union leaders. A similar trend was observed in earlier studies (Acharji ,1980; Sood, 1984)). Sood(1984) found that an Indian trade union leader, on an average, had the knowledge of three languages.

\subsection{Membership in Social Service Organisations}

As far as their membership in social service organisations is concerned, about one-thirds of them were members in some social service organisations such as Red Cross Society, regional associations, and games and sports bodies. They actively participated in these organisations. It is significant to note that nearly one-thirds of them were members of various national and 
regional political parties. With respect to these aspects, one of the earlier studies (Madhusudana Rao, 1984) found that a few trade union leaders had political affiliations and they did not find much time to engage in social service activities.

6.7 Present Employment: With regard to their employment background, the respondent union leaders were in a wide variety of jobs ranging from Foreman to Helper. However, about 70\% of them were in the worker cadre in the roles such as operator, technician, fabricator, crane operator and assembler. About $10 \%$ of them were in the Foreman cadre. 
Table 1. General Background

\begin{tabular}{|c|c|c|}
\hline Items & No. Respondents & $\%$ \\
\hline \multicolumn{3}{|l|}{ Age (years) } \\
\hline $35-45$ & 27 & 33.33 \\
\hline $46-55$ & 40 & 49.38 \\
\hline 56 and above & 14 & 17.28 \\
\hline \multicolumn{3}{|l|}{ Rural-Urban Background } \\
\hline Rural & 37 & 45.68 \\
\hline Urban & 44 & 54.32 \\
\hline \multicolumn{3}{|l|}{ Religion } \\
\hline Hindu & 75 & 92.59 \\
\hline Muslim & 4 & 4.94 \\
\hline Christian & 1 & 1.23 \\
\hline Sikh & 1 & 1.23 \\
\hline \multicolumn{3}{|l|}{ Education } \\
\hline General & 27 & 33.33 \\
\hline Technical & 54 & 66.67 \\
\hline \multicolumn{3}{|l|}{ Languages known } \\
\hline Hindi and English & 44 & 54.32 \\
\hline Hindi only & 22 & 27.16 \\
\hline Hindi, English and one regional language & 12 & 14.81 \\
\hline Hindi, English and two regional language & 3 & 3.70 \\
\hline \multicolumn{3}{|l|}{ Membership in social service organisations } \\
\hline Yes & 23 & 28.40 \\
\hline No & 58 & 71.60 \\
\hline \multicolumn{3}{|l|}{ Membership in political parties } \\
\hline Yes & 31 & 38.27 \\
\hline No & 50 & 61.73 \\
\hline \multicolumn{3}{|l|}{ Job Responsibility } \\
\hline Worker cadre -Technical & 56 & 69.14 \\
\hline Foreman cadre & 6 & 7.41 \\
\hline Clerical cadre & 8 & 9.88 \\
\hline Security services & 3 & 3.70 \\
\hline Helper cadre & 4 & 4.94 \\
\hline Sweeper & 1 & 1.23 \\
\hline Former Employees & 3 & 3.70 \\
\hline
\end{tabular}

\section{Union Background}

The study made an attempt to find out the reasons for taking up leadership position, union experience, indicators of success as a leader, the difficulties the leaders face and participation 
of the leaders in union related conferences and training programmes. The data is presented in Table 2.

\subsection{Present Position in the Union and Union Experience}

The population of the study was 214 executive committee members and 11 officer bearers, out of which 72 (89\%) executive committee members and eight (11\%) officer bearers such as deputy president, vice-presidents, general secretary, assistant secretary, and treasurer were covered in this study. The union experience of the respondent union leaders ranged from three to 29 years with an average union experience of 23 years. More than three-fourths of them had 21 and above years of union experience. When compared to the studies conducted by Punekar and Madhuri, (1967), and Acharji (1980), this study found a sharp increase in the union experience of the trade union leaders.

\subsection{Reasons for Taking up Union Leadership}

When the respondents were asked to give reasons for taking up union leadership, they gave varied responses. A great majority $(90.12 \%)$ of the respondent leaders stated that the main reason was to serve the working class. This is consistent with the findings of the earlier studies (Punekar and Madhuri; 1967, Acharji, 1980; Madhusudana Rao, 1984). The other reasons were: 'someone convinced to take union leadership' 'to get more recognition' and 'to get leverage for political activities'. These reasons came from a small group of the respondents. It is significant to note that about $5 \%$ of the respondents thought of union leadership position as a solution for their survival when management penalized them. In contrast, Masihi (1985) found that a majority of employees took up leadership positions with some reluctance because of some social influence. According to Sood (1984), the desire to serve and the desire to obtain social prestige and influence were the main motives for taking up a leadership role.

\subsection{Level of Union Association}

As far as their level of union association is concerned, a great majority (83\%) of them were confined to union activities at the local union level only. This is consistent with the earlier study conducted by Acharaji (1980). However, a small percentage of the respondent union leaders were associated with local, state, national and international level union activities.

\subsection{Trade Union Methods}

When the respondents were asked to state their methods of preference to deal with the management on employee issues, it is significant to note that, all of them preferred mutual discussion, negotiations and legal methods only. It is important to note that none of the respondent union leaders favoured involvement of political leaders, strikes or any other militant methods to address the concerns of union members. Hiremath (1990) also made similar observations on effective methods of resolving employee problems. His study found that a majority of trade union leaders preferred voluntary methods to radical methods. However, Acharji (1980) asserted that communist leaders would not mind resorting to strikes, whereas non-communist leaders preferred legal methods. Sood (1984) also pointed out that 


\section{Macrothink

the leaders considered negotiations to be the best method of resolving industrial disputes, but willing to resort to demonstrations and strikes, if required.

\subsection{Success Indicators and Difficulties}

An inquiry was made in this study to find the views of the respondent union leaders to find out the indicators of union leadership success and the difficulties they faced as union leaders. There were multiple viewpoints from the respondents in this regard. It is very significant to note that, according to nearly three-fourth of them, access to members was the indicator of a leader's success. However, nearly half of the respondents also viewed that rapport with management was another important indicator of their success. Successful track record of handling issues and collective bargaining agreement followed this factor. When asked to state the difficulties they encountered as union leaders, an overwhelming majority (83\%) of them pointed out that, increasing expectations of the members was the major difficulty they faced. The other difficulties were: rigid attitude of management, lack of political background, and lack of enough time to devote for union activities.

\subsection{Publications, Participation in Conferences and Training}

This study made an attempt to find out publication of articles by the leaders on trade union related topics, participation of union leaders in trade union seminars and conferences and training programmes. It is significant to note that about $15 \%$ of them published some papers/booklets on trade union or employee related issues. As far as the earlier study (Acharji, 1980 ) is concerned, it was $18.57 \%$. Thus one can see a sharp decline in publication of papers by trade union leaders. However, it is heartening to note that about $87 \%$ of the respondents attended various seminars or conferences on trade union related subjects during the last year. When compared to earlier study (Acharji, 1980), there was a sharp increase in this case. Another important observation is that $95 \%$ of the respondents felt that it is important to undergo training on trade unionism, but $52 \%$ only could attend such type of training. 
Table 2. Union Background

\begin{tabular}{|c|c|c|c|c|c|}
\hline Item & $\begin{array}{c}\text { No. of } \\
\text { respondents }\end{array}$ & $\%$ & Item & $\begin{array}{c}\text { No. of } \\
\text { respondents }\end{array}$ & $\%$ \\
\hline \multicolumn{3}{|c|}{ Present position in the Union } & \multicolumn{3}{|l|}{ Preferred method of union } \\
\hline Deputy president & 1 & 1.23 & $\begin{array}{l}\text { Mutual discussion and } \\
\text { negotiations }\end{array}$ & 81 & 100.00 \\
\hline Vice-President & 3 & 3.70 & \multicolumn{3}{|l|}{ Indicators of success* } \\
\hline Secretary & 1 & 1.23 & Access to members & 60 & 74.07 \\
\hline Assistant secretary & 3 & 3.70 & Rapport with management & 39 & 48.15 \\
\hline Treasurer & 1 & 1.23 & $\begin{array}{l}\text { Track record of handling } \\
\text { employees' issues }\end{array}$ & 34 & 41.98 \\
\hline $\begin{array}{l}\text { Executive committee } \\
\text { members }\end{array}$ & 72 & 88.89 & $\begin{array}{l}\text { Track record of collective } \\
\text { agreements }\end{array}$ & 30 & 37.04 \\
\hline \multicolumn{3}{|l|}{ Union Experience (years) } & \multicolumn{3}{|l|}{ Difficulties* } \\
\hline 10 and Below & 11 & 13.58 & $\begin{array}{l}\text { Too much expectations of } \\
\text { members }\end{array}$ & 67 & 82.72 \\
\hline 11 to 20 & 8 & 9.88 & Rigid management & 11 & 13.58 \\
\hline 21 and above & 62 & 76.54 & $\begin{array}{l}\text { Lack of political } \\
\text { background }\end{array}$ & 9 & 11.11 \\
\hline \multicolumn{3}{|c|}{ Reasons for taking union leadership* } & $\begin{array}{l}\text { Lack of time to devote on } \\
\text { union issues }\end{array}$ & 7 & 8.64 \\
\hline $\begin{array}{l}\text { Wanted to serve working } \\
\text { class }\end{array}$ & 73 & 90.12 & \multicolumn{3}{|l|}{ Did you Publish } \\
\hline $\begin{array}{l}\text { Interested from school } \\
\text { days }\end{array}$ & 37 & 45.68 & Yes & 12 & 14.81 \\
\hline Someone convinced & 23 & 28.40 & No & 69 & 85.19 \\
\hline To get more recognition & 19 & 23.46 & \multicolumn{3}{|l|}{ Did you Participate in seminars } \\
\hline $\begin{array}{l}\text { To get leverage for } \\
\text { political activities }\end{array}$ & 11 & 13.58 & Yes & 71 & 87.65 \\
\hline To make use of privileges & 6 & 7.41 & No & 10 & 12.35 \\
\hline $\begin{array}{l}\text { Penalized by } \\
\text { management }\end{array}$ & 4 & 4.94 & \multicolumn{3}{|l|}{ Is Leadership training required } \\
\hline \multicolumn{3}{|l|}{ Level of Union Association } & Yes & 77 & 95.06 \\
\hline Local & 67 & 82.72 & No & 4 & 4.94 \\
\hline Local and State & 6 & 7.41 & \multicolumn{3}{|l|}{ Did you received training } \\
\hline Local, State and National & 4 & 4.94 & Yes & 42 & 51.85 \\
\hline $\begin{array}{l}\text { Local, State, National } \\
\text { and International }\end{array}$ & 4 & 4.94 & No & 39 & 48.15 \\
\hline
\end{tabular}

Note:* Data sorted in descending order. Percentages do not total $100 \%$ due to multiple responses 


\section{Trade Union Management}

The respondent union leaders' were asked for their views asked on union management aspects such as union elections, decision making process, communication process, leader-member access, union finance, factionalism and rivalry. The data is presented in Table 3.

\subsection{Union Elections}

Elections for the position of union leaders were conducted for every two years. When asked about their views on the conduct of elections, $85 \%$ of the respondent union leaders mentioned that the union elections were conducted in a fair manner, giving opportunity to every candidate to present their manifestos to the union members.

\subsection{Decision Making}

When asked 'who are involved in the decision making process of trade union?' about two-thirds of the respondent union leaders stated that office bearers and executive committee members were involved in the decision making. According to about one-fifth of the respondents, office bearers and presidents were involved in this process. However, about $6 \%$ of the respondents alleged that presidents only took the decisions without involving anyone else. Generally, the mode of decision making was arriving at a consensus. However, at times voting was also conducted. It is interesting to note that an overwhelming majority of the respondents were satisfied with the union decision making process. The respondents who were not happy with the decision making process alleged that many times views of all people concerned were not taken into consideration while arriving at a consensus. At times, office bearers took arbitrary decisions on the spot without consulting the executive committee. They suggested that secret ballot among all executive committee members should be the method of decision making for all major issues which affect a large section of members.

\subsection{Leader-Member Access}

Accessibility to the members is one of the factors of a leader's success. With regard to this, $95 \%$ of the respondent union leaders stated that they were easily accessible to their members, whereas the remaining $5 \%$ of respondent leaders admitted that they were not easily accessible due to some personal constraints. Other than formal meetings, leaders and members could meet, informally, in their respective offices, informal get-togethers during festivals, weddings and some other parties. Whenever the leaders and members met, they used to discuss various issues such as union related issues (77\%), general issues (58\%), personal and family matters $(14 \%)$ and political issues (4\%). It is significant to note that about $88 \%$ of the respondent leaders were happy with the leader-member access. The remaining $12 \%$ wanted to have more access to their members.

\subsection{Communication}

As far as communication between the union and the members is concerned, nearly three-fourths of respondents felt that the members were given adequate information, to a great extent, formally through notice board bulletins. According to a majority of the 


\section{Macrothink

respondent union leaders, adequate information was given to the members informally also. An overwhelming majority (88\%) of the respondents expressed their happiness with the existing communication system between the union and its members. However, some of the respondents, particularly, who were not satisfied with the present communication system suggested that there should be a systematic way of communication via both online and offline. All policy-related discussions should be shared among the members without considering it as classified information.

\subsection{Finance}

It is interesting to note that $85 \%$ of the respondent leaders were happy with the union's financial position. The union was prudent in the management of its funds. It gave detailed financial reports to its members. However, some of the respondents suggested that the union should generate more funds legally so that the quality and quantity of union activities could be enhanced further.

\subsection{Factionalism and Rivalry}

It is significant to note that $86 \%$ of the respondent leaders admitted that there was a certain factionalism and rivalry within the union. It used to surface during elections (90\%), union meetings (39\%), and during joint committee meetings (7\%). The study found that the major reason for this situation was personal differences $(77 \%)$ among the union leaders. This was followed by political differences (36\%). Power struggle, ideological difference, deliberate attempt by one leader to undermine the influence of another, regional differences among the leaders, and management's encouragement were some other reasons for factionalism and rivalry within the union. Almost one-thirds of the respondent leaders were under the opinion that the intra-union rivalry weakened the union's position. They suggested that the leaders should set aside their personal difference and work for a common cause. Extensive internal discussions on the issues, considering the viewpoint of all the people concerned before taking a decision, would minimize this problem. 
Table 3. Union Management

\begin{tabular}{|c|c|c|c|c|c|}
\hline Items & $\begin{array}{l}\text { No. of } \\
\text { Respondents }\end{array}$ & $\%$ & Items & $\begin{array}{l}\text { No. of } \\
\text { Respondents }\end{array}$ & $\%$ \\
\hline Elections & & & Communication & & \\
\hline $\begin{array}{l}\text { Union elections are } \\
\text { conducted in a fair } \\
\text { manner }\end{array}$ & & & $\begin{array}{l}\text { Union gives } \\
\text { adequate } \\
\text { information to } \\
\text { workers formally }\end{array}$ & & \\
\hline Yes & 69 & 85.19 & $\begin{array}{l}\text { Yes, to a great } \\
\text { extent }\end{array}$ & 60 & 74.07 \\
\hline No & 11 & 13.58 & Yes, to some extent & 15 & 18.52 \\
\hline Decision-Making & & & Not much & 6 & 7.41 \\
\hline $\begin{array}{l}\text { Who are involved in } \\
\text { union decisions }\end{array}$ & & & $\begin{array}{l}\text { Union gives } \\
\text { adequate } \\
\text { information to } \\
\text { workers informally }\end{array}$ & & \\
\hline $\begin{array}{l}\text { Office bearers \& } \\
\text { executive committee } \\
\text { member }\end{array}$ & 58 & 71.60 & $\begin{array}{l}\text { Yes, to a great } \\
\text { extent }\end{array}$ & 55 & 67.90 \\
\hline $\begin{array}{l}\text { Office bearers with } \\
\text { president }\end{array}$ & 18 & 22.22 & Yes, to some extent & 20 & 24.69 \\
\hline President alone & 5 & 6.17 & Not much & 6 & 7.41 \\
\hline $\begin{array}{l}\text { Mode of } \\
\text { Decision-making }\end{array}$ & & & $\begin{array}{l}\text { Satisfied with } \\
\text { communication }\end{array}$ & & \\
\hline Conesus & 70 & 86.42 & Yes & 71 & 87.65 \\
\hline Voting & 11 & 13.58 & $\mathrm{No}$ & 10 & 12.35 \\
\hline $\begin{array}{l}\text { Satisfied with } \\
\text { decision making } \\
\text { process }\end{array}$ & & & Finance & & \\
\hline Yes & 69 & 85.19 & $\begin{array}{l}\text { Satisfied with union } \\
\text { finance }\end{array}$ & & 0.00 \\
\hline No & 12 & 14.81 & Yes & 69 & 85.19 \\
\hline $\begin{array}{l}\text { Leader- Member } \\
\text { Access }\end{array}$ & & & No & 12 & 14.81 \\
\hline $\begin{array}{l}\text { Do you Accessible to } \\
\text { members }\end{array}$ & & & \multicolumn{3}{|c|}{$\begin{array}{l}\text { Is there any factionalism\& rivalry in the } \\
\text { union }\end{array}$} \\
\hline Yes & 77 & 95.06 & Yes & 70 & 86.42 \\
\hline No & 4 & 4.94 & No & 11 & 13.58 \\
\hline $\begin{array}{l}\text { Subjects discussed } \\
\text { with members* }\end{array}$ & & & \multicolumn{3}{|c|}{ Reasons for factionalism* } \\
\hline Union matters & 62 & 76.54 & Personal differences & 62 & 76.54 \\
\hline General matters & 58 & 71.60 & Political differences & 29 & 35.80 \\
\hline
\end{tabular}




\begin{tabular}{|c|c|c|c|c|c|}
\hline Personal matters & 11 & 13.58 & Power struggle & 19 & 23.46 \\
\hline Political matters & 3 & 3.70 & $\begin{array}{l}\text { Ideological } \\
\text { difference }\end{array}$ & 14 & 17.28 \\
\hline $\begin{array}{l}\text { Satisfied with } \\
\text { accessibility to } \\
\text { Members }\end{array}$ & & & $\begin{array}{l}\text { To undermine the } \\
\text { influence of others }\end{array}$ & 10 & 12.35 \\
\hline Yes & 71 & 87.65 & Regional difference & 7 & 8.64 \\
\hline No & 10 & 12.35 & $\begin{array}{l}\text { Management's } \\
\text { encouragement }\end{array}$ & 4 & 4.94 \\
\hline \multirow{3}{*}{\multicolumn{3}{|c|}{$\begin{array}{l}\text { Note: } * \text { Data sorted in descending order. } \\
\text { Percentages do not total } 100 \% \text { due to multiple } \\
\text { responses }\end{array}$}} & \multicolumn{3}{|c|}{ When rivalry comes to surface* } \\
\hline & & & During election & 73 & 90.12 \\
\hline & & & $\begin{array}{l}\text { During union } \\
\text { meetings }\end{array}$ & 24 & 29.63 \\
\hline & & & $\begin{array}{l}\text { During joint } \\
\text { consultations }\end{array}$ & 6 & 7.41 \\
\hline
\end{tabular}

\section{Leaders 'Perspective on HR Practices}

The respondent union leaders were asked to give their views on changes that took place over the past five years on various HR practices of the Plant. Their responses are presented in Table 4.

It is observed that a single largest group (44\%) of the respondent leaders felt that there was no change in generation of employment opportunities in their Plant for the last five years. However, $38 \%$ of them opined that the employment opportunities had improved. With regard to production facilities, it is significant to note that an overwhelming majority $(86 \%)$ of the respondents felt that there was an improvement. Incidentally, they also felt that the intensity of work and workload had also increased. It is significant to note that, according to a majority $(68 \%)$ of the respondents, there was no change with respect to job security. Moreover, it is interesting to note that nearly one-fourths of the respondent leaders felt that job security for employees had increased. With regard to promotional opportunities, almost every alternative respondent reported' no change'. However, one-thirds of them opined that the opportunities for upward movement in their Plant had increased. Even learning opportunities had also improved as viewed by more than half of the respondent leaders.

It is heartening to note that nearly two-thirds of the respondents perceived that job satisfaction among the workers of their plant had improved over the last five years. According to a simple majority of the respondents, there was no change in wage rates or incentive payments. However, with respect to employee benefits and services, a majority of them felt that there was an improvement. As far as disciplinary actions and employee grievances are concerned, a simple majority of the respondents felt 'no change' over the last five years. Interestingly, three-fourths of the respondent leaders opined that the working conditions in the plant had improved over a period of the last five years. 


\section{Macrothink}

With regard to functioning of joint consultation forums in the plant, about two-fifths of the respondents perceived improvement and by and large the same number of the respondents believed that there was 'no change'. However, above two-thirds of the respondents felt that there was an overall improvement in management-union relations during the last five years. This is consistent with the findings of the one of the earlier studies (Dhal and Srivavastava, 2002).Contrary to the findings of one of the earlier studies (Singh and kulkarni, 2013), a great majority of the respondent leaders reported that their understanding of business over a period of time had increased. They became more sensitive to management concerns. An overwhelming majority of them were ready to sacrifice some of the immediate sectional interests of trade unions, keeping in view the long term interests of the company. This clearly indicates a trend towards responsible trade unionism and consistent with the observations made by Sodhi (2013).

Table 4. Perspective of Union Leaders on HR practices

\begin{tabular}{|c|c|c|c|c|c|}
\hline Items & $\begin{array}{l}\text { No. of } \\
\text { Respondents }\end{array}$ & $\%$ & Items & $\begin{array}{l}\text { No. of } \\
\text { Respondents }\end{array}$ & $\%$ \\
\hline \multicolumn{3}{|c|}{ Employment opportunities } & \multicolumn{3}{|c|}{ Employee benefits and services } \\
\hline Increased & 31 & 38.27 & Increased & 45 & 55.56 \\
\hline Reduced & 14 & 17.28 & Reduced & 3 & 3.70 \\
\hline No change & 36 & 44.44 & No change & 28 & 34.57 \\
\hline $\begin{array}{l}\text { Production } \\
\text { facilities }\end{array}$ & & & \multicolumn{3}{|c|}{ Disciplinary actions } \\
\hline Increased & 70 & 86.42 & Increased & 27 & 33.33 \\
\hline Reduced & 3 & 3.70 & Reduced & 12 & 14.81 \\
\hline No change & 8 & 9.88 & No change & 42 & 51.85 \\
\hline Workload & & & \multicolumn{3}{|c|}{ Employee grievances } \\
\hline Increased & 69 & 85.19 & Increased & 27 & 33.33 \\
\hline Reduced & 1 & 1.23 & Reduced & 4 & 4.94 \\
\hline No change & 11 & 13.58 & No change & 41 & 50.62 \\
\hline Job security & & & \multicolumn{3}{|c|}{ Quality of working conditions } \\
\hline Increased & 19 & 23.46 & Improved & 60 & 74.07 \\
\hline Reduced & 7 & 8.64 & Reduced & 5 & 6.17 \\
\hline No change & 55 & 67.90 & No change & 16 & 19.75 \\
\hline \multicolumn{3}{|c|}{ Promotional opportunities } & \multicolumn{3}{|c|}{ Joint consultation } \\
\hline Increased & 27 & 33.33 & Improved & 35 & 43.21 \\
\hline Reduced & 12 & 14.81 & Reduced & 12 & 14.81 \\
\hline No change & 42 & 51.85 & No change & 34 & 41.98 \\
\hline \multicolumn{3}{|c|}{ Learning opportunities } & \multicolumn{3}{|c|}{ Union-management relations } \\
\hline Increased & 43 & 53.09 & More Cordial & 63 & 77.78 \\
\hline Reduced & 6 & 7.41 & More strained & 6 & 7.41 \\
\hline No change & 32 & 39.51 & No change & 12 & 14.81 \\
\hline \multicolumn{3}{|c|}{ Job satisfaction } & \multicolumn{3}{|c|}{ Trade union's understanding of business is } \\
\hline
\end{tabular}




\begin{tabular}{|c|c|c|c|c|c|}
\hline \multirow{2}{*}{\begin{tabular}{|l|} 
\\
Increased \\
\end{tabular}} & \multirow[b]{2}{*}{52} & \multirow[b]{2}{*}{64.20} & \multicolumn{3}{|c|}{ increased } \\
\hline & & & Yes & 68 & 83.95 \\
\hline Reduced & 13 & 16.05 & No & 13 & 16.05 \\
\hline No change & 16 & 19.75 & \multicolumn{3}{|c|}{$\begin{array}{l}\text { Trade union became more sensitive to } \\
\text { management' concern }\end{array}$} \\
\hline \multicolumn{3}{|l|}{ Wages } & Yes & 48 & 59.26 \\
\hline Increased & 30 & 37.04 & No & 33 & 40.74 \\
\hline Reduced & 6 & 7.41 & \multicolumn{3}{|c|}{$\begin{array}{l}\text { Keeping in view the company's long term } \\
\text { interests, union is ready to sacrifice }\end{array}$} \\
\hline No change & 45 & 55.56 & Yes & 69 & 85.19 \\
\hline \multicolumn{3}{|c|}{ Incentive payment } & No & 11 & 13.58 \\
\hline Increased & 28 & 34.57 & & & \\
\hline Reduced & 12 & 14.81 & & & \\
\hline No change & 41 & 50.62 & & & \\
\hline
\end{tabular}

\section{Conclusion}

The analysis of the plant level trade union leaders' profile leads to the conclusion that an average trade union leader is an employee who is middle aged, educated, urbanite with multilingual proficiency. He has joined the union with a genuine interest of the serving working class and has put up 23 years of union experience. He has confined his union activities, predominantly, to the plant level and firmly believes that mutual discussions, negotiations and legal methods are the best means of achieving union objectives. He considers that his success as the union leader predominately depends on his access to the members of the union. However, increasing expectations of the members was a major difficulty the union leader faces. He attends trade union related conferences and seminars and updates himself on the overall industrial relations and trade union situation across the country.

He is satisfied with the manner of conducting union elections, union decision making process, communications system between the union and its members and union finance. Being an employee leader of the plant, in addition to formal meetings, he has opportunities to meet the members informally in their respective offices, informal get-togethers during festivals, weddings and some other parties. Whenever he meets the members, the discussions between the leader and members go beyond union matters. They keep on discussing personal and family matters as well as political issues. Thus the leader is accessible to his members, which is a key factor for the success of the leader. Interestingly, an average union leader admits the fact that there is intra-union rivalry and factionalism within the union, which generally comes to surface during union elections. He believes that the personal differences among the union leaders is a major source for this situation. He suggests that extensive internal discussions on the issues, considering the viewpoint of all the people concerned, would minimize this problem. 


\section{Macrothink

The analysis relating to the trader union leaders' perspective on various HR practices leads to the conclusion that an average trade union leader is happy with the present HR practices existing in the Plant. Though there is a feeling that the intensity of work and workload have increased over the past five years, he believes that improved quality of working conditions, increased employee benefits and services, and learning and development opportunities make the employees happy. Being an employee leader (insider), he understands the business of the Plant, and its problems. He is sensitive to management concerns and subsequently willing to sacrifice the sectional interests of the members for the long term benefit of the plant. The paternalistic attitude of management, its balancing efforts to integrate the employees interests and organisational interests contributed to this positive situation. Thus, finally it may be concluded that the context of the union, in which it operates makes a difference in its perspective with respect to the HR practices and union-management cooperation.

\section{References}

Acharji, N. (1980). Trade Union Leadership Profile. New Delhi: Ambika Publications.

Day, D., \& Harrison, M. (2007). A multilevel, identity-based approach to leadership development. Human Resource Management Review, 17(4), 360-73. http://dx.doi.org/10.1016/j.hrmr.2007.08.007

Dhal, M., \& Srivavastava, K.B.L. (2002). Trade unionism: perceptions and attitudes of workers, managers and leaders. The Indian Journal of Industrial Relations, 38(2), 177-198.

Hiremath, S. L. (1990).Trade Union Leadership: An Industrial Relations Approach, Jaipur: Arihant publishers.

Madhusudana Rao, M. (1984). Union leadership profile in Visakhapatnam. The Indian Journal of Industrial Relations, 19(4), 484-501.

Masihi, E. (1985).Trade Union leadership in India: A Sociological Perspective. New Delhi: Ajanta Publications.

Piccolo, R., \& Colquitt, J. (2006).Transformational leadership and job behaviors: the mediating role of core job characteristics. Academy of Management Journal, 49(2), 327-40. http://dx.doi.org/10.5465/AMJ.2006.20786079

Punekar, S.D., and Madhuri, S. (1967).Trade union Leadership in India: A survey, Bombay: Lalvani Publishing House.

Sheth, N. R., \& Jain, S. P. (1968). The status and role of local union leaders. Indian Journal of Industrial Relations, 44(1), 70-88.

Singh, I. S., \& Kulkarni, V. (2013). Trade unionism in India - perceptions \& future. The Indian Journal of Industrial Relations, 49(1), 35-43.

Sodhi J., S. (2013). Trade unions in India. The Indian Journal of Industrial Relations, 49(2), 169-184. 
Sood, S. (1984).Trade union leadership in India: A Case Study. New Delhi: Deep \& Deep publications.

Walumbwa, F., Avolio, B., \& Zhu, W. (2008). How transformational leadership weaves its influence on individual job performance: the role of identification and efficacy beliefs. Personnel Psychology, 61(4), 793-825. http://dx.doi.org/10.1111/j.1744-6570.2008.00131.x 